\title{
THE DETERMINANTS OF FTSE4 GOOD BURSA MALAYSIA
}

\author{
Nor ‘Asyiqin Abu*, Prof. Madya Dr Hajjah Hanim Norza Baba, Siti Aisyah Basri, Zaleha \\ Mahat \\ Faculty of Accountancy, Universiti Teknologi MARA Melaka
}

\begin{abstract}
This study was conducted to identify the factors that influence the companies listed in Bursa Malaysia to be indexed as FTSE4Good Bursa Malaysia (F4GBM). The companies awarded as F4GBM are those with good sustainable practices. This study investigates the potential factors that explain the good sustainable practice (i.e. corporate size, financial performance, industry attachment and sharia-compliant). Analysis reveals that only corporate size which proxy by market capitalization has significant relationship with good sustainable practice.
\end{abstract}

Keywords: Sustainability, Firm characteristics, FTSE4Good, Corporate Social Responsibility (CSR)

\section{INTRODUCTION}

In 2014, Bursa Malaysia Bhd announced the launch of the Environmental, Social and Governance (ESG) Index. Known locally as the FTSE4Good Bursa Malaysia (F4GBM) Index, it requires Malaysian companies to innovate and adopt more sustainable practices in order to comply with this new mandate. Developed in collaboration with FTSE as part of the globally benchmarked FTSE4Good Index Series, the F4GBM Index is aligned with other leading global ESG frameworks such as the Global Reporting Initiative and the Carbon Disclosure Project (Bursa Malaysia, 2014).

According to this new mandate, all constituents of the F4GBM Index must meet internationally benchmarked criteria that measure things such as the effort put into environmental conservation, the impact of social responsibility initiatives on the community, as well as the practice of good governance through responsible and ethical decision-making.

The index also forces companies to look at value from a non-financial perspective such as a company's environmental and societal initiatives. The F4GBM Index is not only in line with the Prime Minister's vision in Budget 2014, but is also the latest step in Bursa Malaysia's sustainability roadmap (Bursa Malaysia, 2014).

As at December 2015, F4GBM Index with a total of 34 constituents, comprising public listed companies (PLCs) from across the small, medium and large market capitalisation segments. Index constituents are drawn from the top 200 shortlisted companies on the FTSE Bursa Malaysia EMAS Index and reviewed in June and December every year (Bursa Malaysia, 2015). FTSE Bursa Malaysia EMAS Index comprises the constituents of the FTSE Bursa Malaysia Top 100 Index and the FTSE Bursa Malaysia Small Cap Index. Being listed in F4GBM Index means the companies have been practicing good sustainability efforts and reporting. The question is, "Does the listed companies shared the same characteristics?" To

*Corresponding author's email: norasyiqin@melaka.uitm.edu.my 
answer this question, this paper will identify the determinants which influence the listing in F4GBM Index.

\section{LITERATURE REVIEW}

The determinants of sustainability reporting can be categorised into two main categories; internal and external. The internal determinant encompasses corporate size, financial performance, social performance, environmental performance, and ownership structure. Conversely, external determinant covers corporate visibility, sector affiliation, country-oforigin, and legal requirements (Hahn and Kuhnen, 2013).

\subsection{Internal Determinants of sustainability reporting}

The most frequently investigated determinants are corporate size and financial performance. Corporate size usually measured by total assets, turnovers, sales, number of employees and market capitalization. From the previous literature, corporate size has a positive effect of sustainability since larger companies are more visible and therefore greater stakeholder scrutiny and pressure. In addition, higher profitability will increase the ability of a company to bear the costs of sustainability reporting (Kent and Monem, 2008). A high level of indebtedness, leverage and gearing can be assumed to decrease the ability and flexibility of a company to bear the cost of reporting or face the consequences of disclosing potentially damaging information (Kent and Monem, 2008).

Social and environmental performance can also measure by the number of fines for environmental wrongdoings. However, the results are inconsistent. According to Belal and Cooper (2001), companies with a lot of wrongdoings may be more actively engaged in reporting to mitigate legitimacy threats. While later study by Brammer and Pavellin (2006) find no significant effect between extend of reporting with social performance.

Ownership structure will also influence reporting practice. Haddock (2005) finds that listed companies disclose a higher level of sustainability information. While Amran and Haniffa (2011) indicate that state-owned and/or government shareholding is associated with a higher extend of sustainability reporting since the respective organizations are subject to more stringent reporting and scrutiny. Brammer and Pavelin (2006) indicate that the quality of reporting is negatively influenced by a concentrated ownership structure and Cormier and Magnan (2003) indicate a positive influence of foreign ownership on the level of sustainable reporting.

\subsection{External Determinants of sustainable reporting}

According to previous literatures, external determinants of sustainability reporting mainly covers aspects of corporate visibility, sector affiliation, country of origin and legal requirements (Hahn and Kuhnen, 2013). Corporate visibility means the exposure of the companies to media. The companies may start sustainability reporting or increase the depth of their disclosure in order to mitigate reputational risk (Haddock and Fraser, 2008). Instead of media exposure, corporate visibility is measured through supply chain position and branding issues.

Businesses to consumer (B2C) companies are more likely to engage in reporting activities rather than business to business (B2B) companies. It means that the extent of reporting depends

[Type here] 
on a company's closeness to market. While company name and brand name confirm a positive influence on the adoption and extent of reporting (Haddock, 2005).

A company's sector or industry attachment is the most frequently addressed external determinant. Companies from industries with high social and environmental impacts may need to engage in sustainable reporting in order to respond to stakeholder pressure (Parsa\&Kouhy, 2008)

A part from industry differences, reporting practices may also vary across countries and regions due to different cultural and social norms or governmental regulations (Sotorrio and Sanshez, 2010). The results indicate differences with respect to adoption, extent, volume and quality of reporting. The study also confirmed an increase in the sustainability reporting is due to tighten regulations.

From the previous literatures, this study has determined that corporate size, financial performance, sector or industry attachment have influence on sustainability reporting. Therefore, this study will use the same factors with an additional determinant 'shariacompliant' to identify whether these factors influence F4GBM listing. Figure 2.1 illustrate the conceptual framework developed for this study.

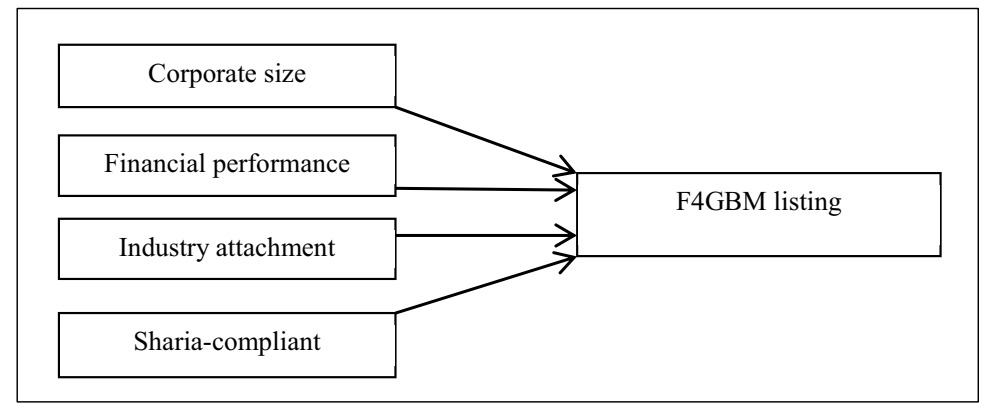

Figure 2.1: Framework of the determinants of FTSE4Good Bursa Malaysia

\section{METHODOLOGY}

The sample used comprises of the companies listed on the FTSE Bursa Malaysia Emas Index as at December 2015. Out of 254 being listed, only 34 entitle as constituents of F4GBM Index. F4GBM listing is considered as dependent variable. Score two (2) was given if the company is constituents of F4GBM Index and score one (1) if otherwise.

The independent variables and their respective measurement are depicted in Table 3.1.

\begin{tabular}{lc}
\hline Independent variables & Measurement \\
\hline Corporate size & - Total assets \\
& - Market capitalization \\
\hline Financial performance & - Revenue \\
& - Total debts \\
\hline
\end{tabular}




\begin{tabular}{ll}
\hline Industry attachment & $\begin{array}{l}\text { Types of sector. FTSE Bursa Malaysia EMAS } \\
\text { Index divided into } 10 \text { sectors }\end{array}$ \\
\hline Sharia-compliant & $\begin{array}{l}\text { Sharia-compliant }=2 \text { or } \\
\text { non-Sharia-compliant }=1\end{array}$ \\
\hline
\end{tabular}

The data of independent variables was obtained from the latest annual report available in Thomson Reuters Datastream. This study has adopted the descriptive statistical analysis technique (SPSS) in analyzing the data.

\section{RESULTS AND DISCUSSION}

\section{Descriptive Analysis}

Descriptive analysis is conducted to generate information about the data collected. Figure 4.1 illustrates the number of company according to sectors. FTSE Bursa Malaysia EMAS Index mainly consists of ten (10) sectors. 32 percent of the constituents come from trade and service sectors, followed by 16 percent from industrial product sectors, almost $10 \%$ from consumers and also finance.

Figure 4.1: Number of samples according to sectors

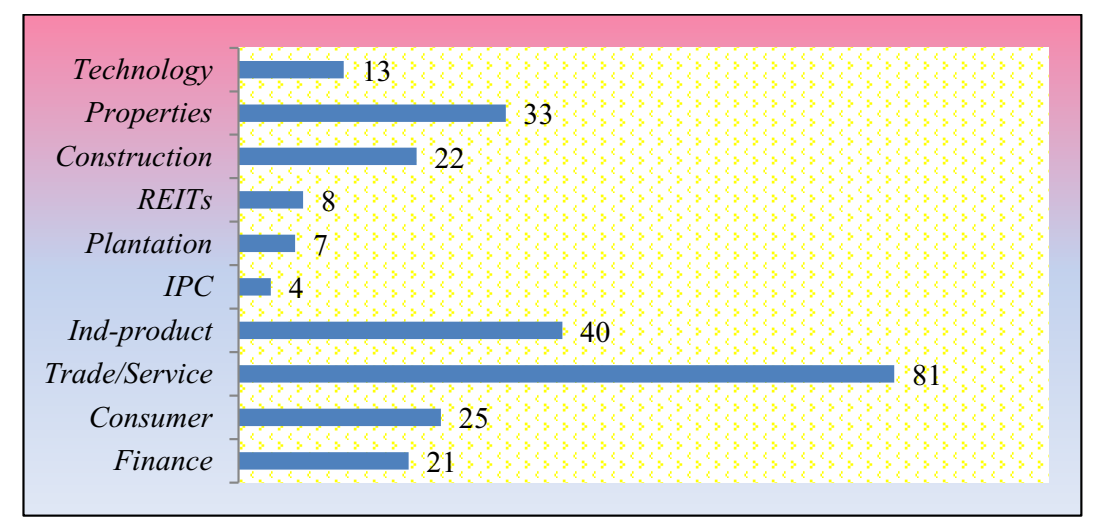

Figure 4.2: Number of F4GBM according to sectors 


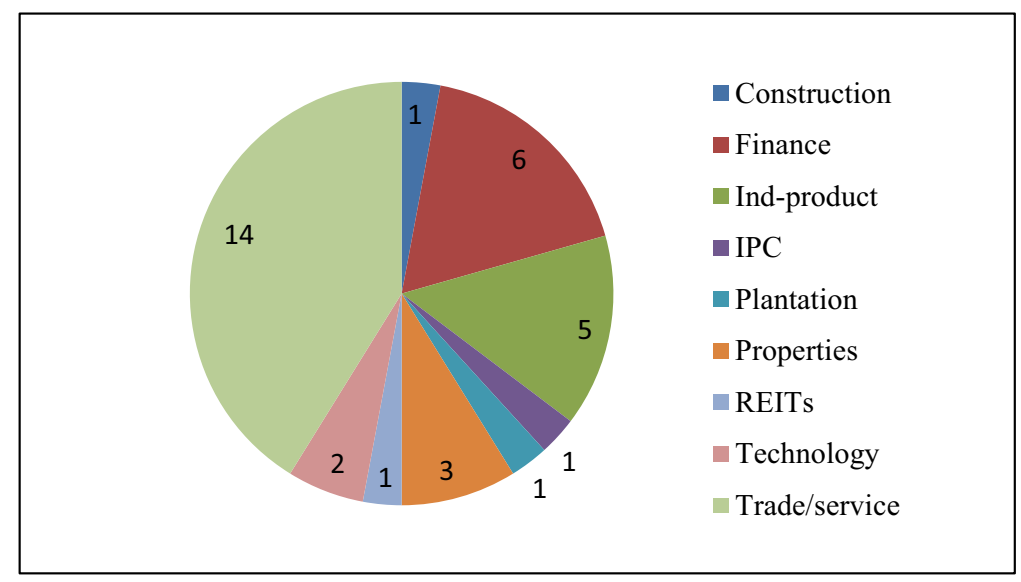

As shown in Figure 4.2, 74 percent of F4GBM constituents are comes from trade and service, finance and industrial products sector. These three sectors conquering F4GBM Index since they are dominate constituents in FTSE Bursa Malaysia EMAS Index.

In addition, trade and service become the majority constituent in F4GBM since this industry is very close to consumer. As mentioned by Haddock (2005), the extent of reporting depends on a company's closeness to market. The term 'close to consumer' is defined as companies that supply goods or services directly into consumer markets instead of supplying to another business entity. Haddock-Fraser and Fraser (2008) demonstrated that companies focused on supplying directly to the end-consumer were more likely to be pro-active in environmental reporting.

Figure 4.3 provides the number of sharia-compliant companies. 76 percent of constituents in FTSE Bursa Malaysia EMAS Index are sharia-compliant. Interestingly, almost 90 percent (30 out of 34) companies listed in F4GBM are sharia-compliant.

In order to be listed as sharia-compliant, the company needs to fulfil the following requirements:

- Companies are not permitted to be involved in any of the following core activities: banking or any other interest-related activity, such as lender and brokerages, but excluding Islamic financial institutions; alcohol; tobacco; gaming; arms manufacturing; life insurance; and, pork and non-halal production, packaging and processing or any other activity related to pork and non-halal food.

- Ratios of debt and debt service in combination that is acceptable and indicative of an appropriate use of leverage relative to their assets.

- Income from cash or near cash equivalents are appropriate levels of receivables to assets.

- Liquid assets to illiquid assets that not exceed the percentages permitted.

- Cash and cash equivalents to total assets that not exceed the percentage permitted. (Bursa Malaysia, 2016)

[Type here] 
As illustrated, most companies prefer to be labelled as sharia-compliance since empirical evidence has proven that performance of sharia stocks tends to be better compared the conventional portfolio return. Investors are also increasingly getting positive about Shariacompliant funds, which have shown to be resilient against the global recession. Due to their relatively low risk and dependability compared to conventional funds, the demand for shariacompliant unit trust funds has grown significantly. So now, even for non-Muslim clients, fund managers recommend a mixed portfolio consisting of sharia-compliant and conventional funds for conservative investors looking to achieve their financial goals (Reddy and Fu, 2014).

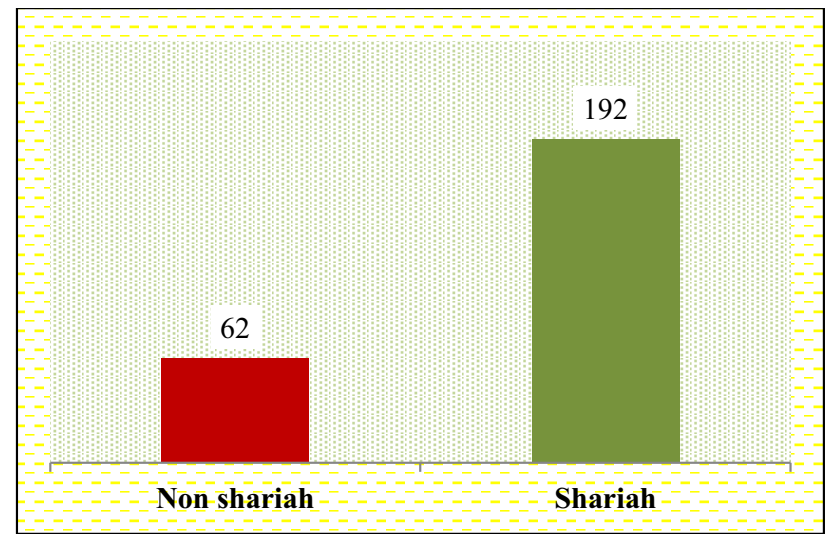

Figure 4.3: Number of samples according to sharia-compliant

\subsection{Corporate size and financial performance}

All proxies of corporate size and financial performance only explain 26 per cent of the variance ( $\mathrm{R}$ Square) in F4GBM listing which highly significant, as indicated by the F-value of $21.386, \mathrm{p}<.05$ in the table below. An examination of the t-value indicates that market capitalization contribute to the prediction of good sustainable practice.

\begin{tabular}{|l|c|r|r|r|}
\multicolumn{5}{c|}{ Model Summary } \\
\hline Model & R & R Square & $\begin{array}{c}\text { Adjusted R } \\
\text { Square }\end{array}$ & $\begin{array}{c}\text { Std. Error of } \\
\text { the Estimate }\end{array}$ \\
\hline 1 & $.506^{\mathrm{a}}$ & .256 & .244 & .28949 \\
\hline
\end{tabular}

a. Predictors: (Constant), TDEBT, MKTCAP, REVENUE, TOTALASSETS

b. Dependent Variable: FTSE4Good

ANOVA ${ }^{a}$

\begin{tabular}{|c|c|c|c|c|c|c|}
\hline & & $\begin{array}{l}\text { Sum of } \\
\text { Squares }\end{array}$ & $\mathrm{df}$ & Mean Square & $\mathrm{F}$ & Sig. \\
\hline \multirow[t]{3}{*}{1} & Regression & 7.169 & 4 & \multirow{3}{*}{$\begin{array}{r}1.792 \\
.084\end{array}$} & \multirow[t]{3}{*}{21.386} & \multirow[t]{3}{*}{$.000^{\mathrm{b}}$} \\
\hline & Residual & 20.783 & 248 & & & \\
\hline & Total & 27.953 & 252 & & & \\
\hline
\end{tabular}

[Type here] 
a. Dependent Variable: FTSE4Good

b. Predictors: (Constant), TDEBT, MKTCAP, REVENUE, TOTALASSETS

Coefficients $^{\mathbf{a}}$

\begin{tabular}{|c|c|c|c|c|c|c|}
\hline \multirow{2}{*}{\multicolumn{2}{|c|}{ Model }} & \multicolumn{2}{|c|}{$\begin{array}{c}\text { Unstandardized } \\
\text { Coefficients }\end{array}$} & \multirow{2}{*}{$\begin{array}{c}\text { Standardized } \\
\text { Coefficients }\end{array}$} & \multirow[b]{2}{*}{$\mathrm{t}$} & \multirow[b]{2}{*}{ Sig. } \\
\hline & & B & Std. Error & & & \\
\hline \multirow[t]{5}{*}{1} & (Constant) & 1.056 & .020 & & 52.430 & .000 \\
\hline & $\begin{array}{l}\text { TOTALASSE } \\
\text { TS }\end{array}$ & $1.434 \mathrm{E}-9$ & .000 & .270 & 1.982 & .049 \\
\hline & REVENUE & $1.290 \mathrm{E}-8$ & .000 & .223 & 2.139 & .033 \\
\hline & MKTCAP & $1.017 \mathrm{E}-8$ & .000 & .399 & 4.157 & .000 \\
\hline & TDEBT & $-1.506 \mathrm{E}-8$ & .000 & -.390 & -2.532 & .012 \\
\hline
\end{tabular}

a. Dependent Variable: FTSE4Good

From the coefficients results, it shown that increasing total assets, revenue and market capitalization was associated with an increase likelihood of good sustainable practice but increasing in total debts was associated with reduction in the likelihood of good sustainable practice.

It is often argued that companies' adoption of sustainability strategies should grant competitive advantages over companies that do not adopt them. In addition, the information on sustainability practices that the company develops and discloses should facilitate the development of better systems of internal control, decision making, and cost saving. Thus, if the goods or services offered by the company possess elements that differentiate them from those of competitors, this will produce differences in sales and turnover (Adams and Zutshi, 2004).

Furthermore, some studies claim that sustainability practices favour stakeholders' legitimation, offering a positive image of the firm and improve its reputation (Adams, 2002). All these opinions support the findings of positive relationship between assets, revenue and market capitalization with good sustainable practice.

\section{CONCLUSION}

This paper explored the issue of whether or not corporate size, financial performance, industry attachment and sharia-compliant were factors influencing good sustainable practice for the FTSE Bursa Malaysia EMAS Index. It was established that a positive statistical association exists between corporate sizes which proxy by market capitalization with good sustainable practice. Interestingly, it was established that 90 percent companies listed in F4GBM are sharia-compliant. Close to consumer companies were more likely to be associated with good sustainable practice since 74 percent of companies listed in F4GBM are from trade and service industries.

The implications of this research are important to policy makers and government as well as investors in terms of identifying which companies are potentially leading the good sustainable practice and identifying why they are taking that action.

[Type here] 
There are a number of limitations to this research study. By its nature it is an exploratory study considering general association patterns within a quantitative data set. As noted above, the good sustainable practice is being associated with close to consumer companies which are trade and service industries. However, further research would be needed to determine whether this perceived need by the companies is responding to an actual need of the consumer.

\section{REFERENCES}

Adams, C. (2002). Internal Organizational Factors Influencing Corporate Social and Ethical Reporting: Beyond Current Theorising, Accounting, Auditing and Accountability Journal 15(2), 223-250.

Adams, C. and Zutshi, A. (2004). Corporate Social Responsibility: Why Business Should Act Responsibly and Be Accountable, Australian Accounting Review 14(3), 31-39.

Amran, A. and Haniffa, R. (2011). Evidence in development of sustainability reporting: case of a developing country. Business Strategy and the Environment, 20 (2011), pp. 141156.

Belal and Cooper, (2001). The absence of corporate social responsibility reporting in Bangladesh. Critical Perspectives on Accounting, 22 (2011), pp. 654-667.

Brammer and Pavelin, (2006).Voluntary environmental disclosures by large UK companies.Journal of Business Finance \& Accounting, 33 (2006), pp. 1168-1188.

Bursa Malaysia,(2014). Bursa Malaysia Announces Launch of Environmental, Social and Governance Index. Retrieved 20 April 2015, from http://www.bursamalaysia.com/corporate/media-centre/media-releases/3081.

Bursa Malaysia,(2015). Bursa Malaysia Announces Constituent Additions to ESG Index. Retrieved 20 April 2015, from http://www.bursamalaysia.com/corporate/mediacentre/media-releases/3853.

Bursa Malaysia,(2016).FTSE Bursa Malaysia Hijrah Shariah Index. Retrieved 11 August 2016, from http://www.bursamalaysia.com/market/islamic-markets/products/islamic-capitalmarket/shariah-compliant-listed-equities.

Cormier, D. and Magnan, M. (2003). Environmental reporting management: a continental European perspective. Journal of Accounting and Public Policy, 22 (2003), pp. 43-62.

Haddock, J. (2005). Consumer influence on internet-based corporate communication of environmental activities: the UK food sector. British Food Journal, 107 (2005), pp. 792-805.

[Type here] 
Haddock, J. and Fraser, I. (2008). Assessing corporate environmental reporting motivations: differences between "close-to-market" and "business-to-business" companies. Corporate Social Responsibility and Environmental Management, 15 (2008), pp. 140155.

Hahn and Kuhnen, (2013). Determinants of sustainability reporting: a review of results, trends, theory, and opportunities in an expanding field of research. Journal of Cleaner Production, 59 (2013), pp. 5-21.

Kent and Monem, (2008). What drives TBL reporting: good governance or threat to legitimacy.Australian Accounting Review, 18 (2008), pp. 297-309.

Parsa, S. and Kouhy, R. (2008). Social reporting by companies listed on the alternative investment market. Journal of Business Ethics, 79 (2008), pp. 345-360.

Reddy, K. and Fu, M. (2014). Does shariah compliant stocks perform better than the conventional stocks? A comparative study of stocks listed on the Australian Stock Exchange. Asian Journal of Finance \& Accounting, 6 (2014), pp.155-170.

Sotorrio, L. and Sanchez, J.L.F. (2010). Corporate social reporting for different audiences: the case of multinational corporations in Spain. Corporate Social Responsibility and Environmental Management, 17 (2010), pp. 272-283.

Djajadikerta, H. G., Roni, S. M., \& Trireksani, T. (2015). Dysfunctional information system behaviors are not all created the same: Challenges to the generalizability of securitybased research. Information \& Management, 52(8), 1012-1024. doi:http://dx.doi.org/10.1016/j.im.2015.07.008 